\title{
Corporate Image Management of Retail Business (Downstream)
}

\author{
Sunisa Dokmaipum1', Napaporn Khantanapha1, Rapeepun Piriyakul² \\ ${ }^{1}$ Graduate School of Business Administration, Southeast Asia University, Bangkok, Thailand \\ ${ }^{2}$ Faculty of Science, Ramkhamhaeng University, Bangkok, Thailand \\ Email: d.sunisa@hotmail.com, napakhan93@gmail.com, rapepunnight@yahoo.com
}

How to cite this paper: Dokmaipum, S., Khantanapha, N. and Piriyakul, R. (2019) Corporate Image Management of Retail Business (Downstream). Open Journal of Business and Management, 7, 892-907. https://doi.org/10.4236/ojbm.2019.72061

Received: March 22, 2019

Accepted: April 19, 2019

Published: April 22, 2019

Copyright (c) 2019 by author(s) and Scientific Research Publishing Inc. This work is licensed under the Creative Commons Attribution International License (CC BY 4.0).

http://creativecommons.org/licenses/by/4.0/

cc) (i) Open Access

\begin{abstract}
This research aimed to investigate the frameworks that help create the remarkable image of the retail stores in terms of environment, shop management and product as well as the ability of the staff to operate the convenience stores. The samples were ten convenience stores. The composition and characteristics of each retail store were observed in terms of their external and internal environments, the atmosphere, products, and staff in order to perform a qualitative analysis of their symbolic and functional images and a quantitative analysis by scoring on each component. Data were then analyzed by descriptive statistics. Using the K-Mean method, these stores were divided into two groups, i.e. good stores and improvement-needed stores. The exploratory factor analysis found that the corporate image management of retail business (Downstream) can be classified into two factors: storefront management and product and customer management.
\end{abstract}

\section{Keywords}

Retail Business, Corporate Image, Store Image, Exploratory Factor Analysis

\section{Introduction}

Business environment factors, such as rapid technological change and borderless marketing, force various businesses to face competition among their own field. Besides, being able to cope with changes, using right strategies help businesses survive and become successful. For instance, the ability to create positive image as a way to promote the organization's reputation that can lead to its own success in the near future.

Organizational reputation is one of the goals that organizations need to manage in order to create stakeholder awareness. Reputation is derived from the im- 
age of the organization in different areas, such as branding, long business, expertise, professionalism, and security of the organization, which often lead to the organizational confidence and recognition, including customer retention and expansion. The positive reputation of the organization in all dimensions requires good administration. In addition, different types of businesses need different types of administration. For example, financial and banking businesses normally focus on creating their corporate image rather than branding image because their many financial products, including newly created ones, can help save the cost of creating their corporate image and customer recognition more easily. On the other hands, the retail stores generally focus on their branch distribution with spatial and temporal supports, which is deemed as corporate image management at the downstream. Therefore, it is the core competency in the creation of organizational image that can be regarded as an organization-level brand.

Corporate image management is one of the important things that organizations should not less consider and value than anything else. Having a good corporate image leads to better attitudes and beliefs followed by sponsorship behavior and customer loyalty. In addition, having a good corporate image can also reflect corporate reputation and performance.

Business growth reflects the efficiency of the management. Organizational management must take into account the positive image of the organization because corporate image is the reflection or the perception of the target audience that the organization communicates through its corporate identity in a variety of ways, such as corporate symbol, messages, brand, services, and personality and uniform of its personnel, towards external target audience. If the target audience has perceived, understood and responded to what the organization communicates, they will recognize the image of that organization. In addition, if the target audience has accumulated it consistent, the corporate image will eventually become the organization's reputation, which leads to confidence and the value of the organization.

The reputation of the organization is developed from the corporate image. The identity perception as mentioned above includes the perception of attitudes, sense, and personal impression that customers have on the organization, which also covers products, services, and shop conditions. This perception can be realized through media, experience of using the services, or organization's management in terms of products, employees, services, and activities, such as the place and time that consumers can access or receive services conveniently.

Business administration generally depends on three parts: upstream, midstream, and downstream. However, for the image management of retail business that focuses on having a large number of retail outlets, the downstream management is very important and quite difficult with several factors because it is involved with a process of delivering products and services that directly meet the needs of their consumers. For the downstream segment of the retail business, there are several significant factors, such as the number of access channels, response at anytime and anywhere, products and services fully meeting the needs, 
the price of products, the environment, product positioning, and most importantly, trained, professional, and service-minded personnel.

Retail business is classified as a downstream business that is handled by its employees who need to work together at each given time for the receiving of job assignment, shop management, product management, and customer management in various activities, such as finance, delivery of products, and fault recovery management. The process of doing activities in a retail store is shown in Figure 1 below.

In the past, the traditional trade or retail business of Thailand was characterized by small grocery stores managed by their owner alone with less investment and a variety of products were procured and sold through the middlemen (wholesalers). The displayed products were often randomly placed based on the convenience and habit of the store owners with no decoration for beauty or customer attraction. As a result, this type of business disappeared because it has been replaced by modern and professional retail businesses with many branches and better management systems, such as 7 - 11, Tesco Lotus, and Big C stores. With a systematic management of both storefront and back office, including stock management, efficient transportation management, and distribution centers, these professional retail businesses have been responded by many customers. Therefore, in the past two decades, the modern trade or retail business in Thailand has been growing rapidly, especially in Bangkok and other main cities. Moreover, with core identities of the stores, such as convenience, modernity, quality and diversity of products, and coverage of services in all areas and times, these modern retail stores can well meet the consumption habits of urban households because their most costs of living are involved with consumer products that they need to buy normally and continuously as shown in Figure 2 below.

The modern trade or retail stores are divided into five categories: 1) department stores, 2) discount stores/hypermarkets/supercenters, 3) supermarkets, 4) convenience stores/express stores/minimarts, and 5) specialty stores. The modern retail stores that are close to and reach a lot of consumers are small convenience stores where basic consumer products are sold and a number of services are provided, such as coffee, ready-to-eat meals, and bakery, including financial and payment services (counter services). With an ability to meet the needs of urban people who are required to race against time, these convenience stores can

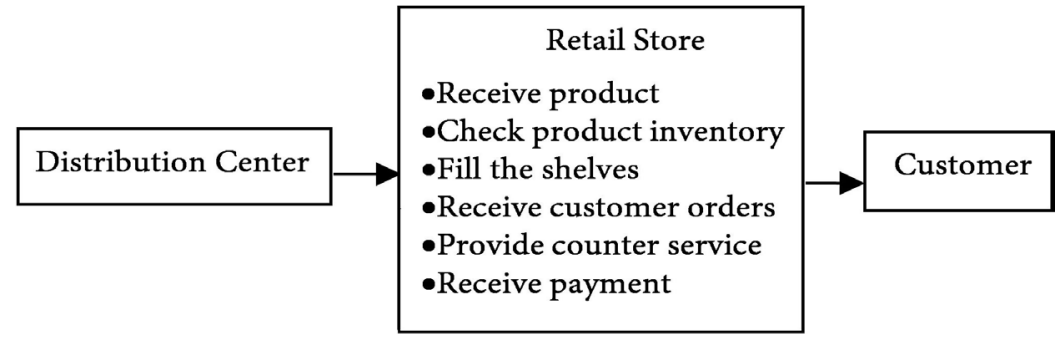

Figure 1. Activities to meet consumer needs at the retail business. 
meet the needs of today's people. In addition, they are often located in communities or places where consumers can easily pass and see them as well as their branches have been continuously expanded and extended to the gas stations to accommodate the purchasing power of the travelling people and surrounding communities.

From Table 1, there were 15,325 convenience stores throughout the country in 2016 that increased from 14,292 stores in 2015, representing 7.2 percent with the expansion of investment in every product brand. The growth of these convenience stores thus means that the competition must be higher as well. Therefore, embedding the image and reputation of the organization into the minds of consumers is an important factor in the business competition.

For convenience stores, their employees are organizational representatives that are an important part of creating a corporate image for consumer perception because they need to interact with each other to communicate and exchange

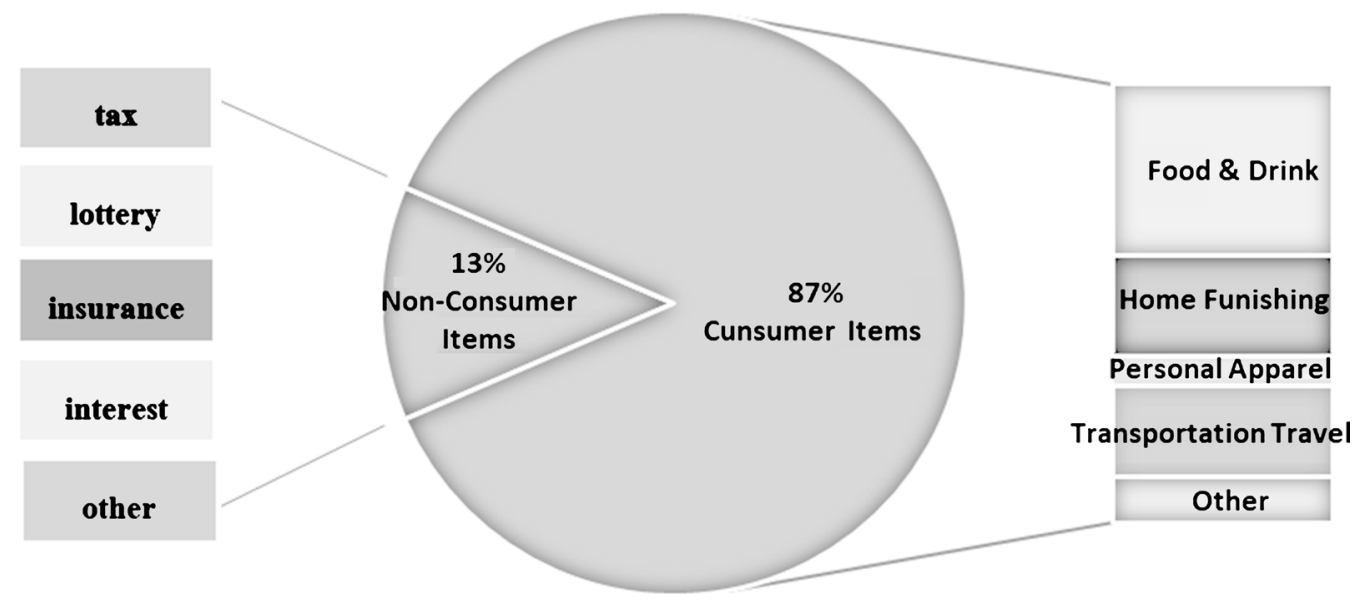

Source: Business/Industrial Trend in 2017-2019 (Modern Retailers), Bank of Ayudhya.

Figure 2. Expected household expenditures in 2018-2019.

Table 1. Number of convenience store in Thailand.

\begin{tabular}{cccccc}
\hline \multirow{2}{*}{ Retailers } & \multicolumn{5}{c}{ Outlets } \\
\cline { 2 - 6 } & 2012 & 2013 & 2014 & 2015 & 2016 \\
\hline 7-Eleven & 6822 & 7429 & 8127 & 8727 & 9500 \\
Lawson 108 & 600 & 540 & 531 & 446 & 498 \\
Family Mart & 764 & 1048 & 1060 & 1080 & 1130 \\
Lotus Express & 1071 & 1305 & 1421 & 1471 & 1477 \\
Mini Big C & 126 & 278 & 316 & 391 & 473 \\
Tops Daily & 119 & 15 & 24 & 51 & 75 \\
Max Value & 32 & 40 & 47 & 48 & 53 \\
Other & 2347 & 2341 & 2037 & 2078 & 2119 \\
Total & 11,881 & 12,996 & 13,563 & 14,292 & 15,325 \\
\hline
\end{tabular}

Source: Krungsri Research Center. 
their demands. Hence, if the customers are positively interacted, both attitudes and behaviors, it will create a good image of the organization. The personnel of these convenience stores thus need to be trained to create awareness and recognition of their role and importance of communicating this image to customers. In addition, they should have service quality [1], pay attention to meet the needs of customers, ensure the security of product delivery and payments, and skillfully manage the products based on the environment of their stores and each group of customers. Moreover, they must have the ability of fault recovery management [2]. These examples are all features that customers recognize and that are integrated as corporate image of such a retail business. This means that the training of the organization's employees for this role is important to the image of the retail stores. In addition to its importance to the competitive market, it is also part of building confidence for customers. Likewise, the researcher sees the importance of the stores image that could excellently reflect both ability and efficiency of the corporate image management. Despite the fact that there are number of previous research that have been done on this certain topic yet none of them focus its research area in Asia (especially Thailand) Moreover, since the research emphasizes on the strength of the existed successful retail stores management there is a high chance that the research could be beneficial for those independently operated small retail stores in the near future.

Thereby, the following essay will be divided into six main parts as followed Introduction, Literature Review, Research Methodology, Results, Discussion and Conclusions and Future Research which will be discussed in details later on.

\section{Literature Review}

From the background and significance of the study, the researchers reviewed literature on the following relevant concepts and theories.

\subsection{Corporate Image}

Corporate image is a significant factor in the company's survival, which shows a positive relationship between the customer/consumer perspectives on the organization and the behavior of the organization. The image is a personal perception that may be different in each person. The image may not be a reflection of the organization, but it is created by the recipients of personal or indirect experience. Thus, the image can change depending on the activities involved or on the development of the organization. In addition, the image may differ from reality, but the organization may be able to direct it to what it wants. Corporate image can be defined as what individuals or consumers perceive about the organization through the media or their direct or indirect experiences, such as word of mouth from acquaintances becoming a sense, attitude, image, and confidence in the organization [3] [4].

To communicate a corporate image to consumers, the organization communicates it through corporate identity that aligns with its business goals and re- 
sults in goals to be recognized and memorized. The retail business presents its unique identities that results in a good corporate image. These identities consist of:

1) Convenience

Convenience is important and is something consumers often consider for their living today. Therefore, for retail stores where products and services are sold and provided to the hurried consumers, the convenience is a key factor and is what should be considered first, such as location or opening hours. Consumers are more likely to get into the services or make purchases in places that are accessible and easy to visit. In addition, the duration of services is also one of the factors in choosing the services [5].

2) Environment

Environment and atmosphere can influence the emotions and feelings of people and are important in creating memory, experience, and image in the future. Many researchers state that the environment, atmosphere, shop design, and smell and relaxation are important factors influencing demand and satisfaction with products and services, attracting more customers, and increasing the opportunity to make decisions to buy or consider products for a longer period [6].

3) Product

Product quality is considered as an important part of enhancing the organization's competitive advantage [7]. Consequently, product quality is a matter of concern for the company. Quality is a complex and difficult concept [8]. At present, there are a variety of meanings or perspectives towards the term "quality." However, one of the most popular definitions was developed by David Garvin of the Harvard Business School (1984), which was mentioned in the article of [9], where he offers the following dimensions of the quality:

- Performance or main functions of the product.

- Features or additional bells and whistles of the product.

- Conformance with standard or expansion of the design and use of users that meet the established standard.

- Reliability or probability that the product will perform well and efficiently over a specified period of time under the specified conditions of use.

- Durability or amount or duration of use that the customers will receive from the product before its physical deterioration or until the product replacement is satisfactory.

- Serviceability or speed, ability and courtesy of repairs.

- Aesthetics or how the product attracts our five senses.

- Customer perceived quality or customer perception of product quality according to company reputation.

In addition, according to Latif Atiyah, the quality products are an essential foundation for customer satisfaction and loyalty as well as for middle-term and long-term profitability [10]. Therefore, if the products meet the expectations of the customers, they will be satisfied or will believe that the products are of acceptable or high quality [8]. 
4) Service

The success of businesses can arise from their good corporate image, which is the result of the quality of standardized services provided by the organization employees to their customers. In addition, the quality of standardized services is considered one of the key factors in building a good image for such brand or organization. According to $\mathrm{Wu}$, the corporate image is a whole perception of corporate branding in the customer memory that reflects their overall impression [11]. The good image of the organization will result in them gaining competitive advantage and value [12], including other factors or results, such as customer satisfaction with service quality, brand loyalty, or even willingness to return to the products of the organization in the future [13] [14] [15].

Good serviced quality is one of the key factors in managing a business that is widely discussed and covers both education and trade. Good service quality means an overall impression of the customers and an assessment of the inferiority or superiority of the organizations in terms of their services [16]. Service quality can be measured by comparing customers' expectations with customer perceptions of actual service performance [17] and the customers will develop a sense during and after service period and compare their satisfaction according to the criteria of services they have received.

Corporate image management, whether in terms of services, stores or products, is important [18] [19]. Good image influences attitudes and trust, motivates satisfaction, and partly drives the decision-making and behavior of purchasing products and services of the organization. Therefore, in order to create and maintain the corporate image to remain, the organizations must build a strong relationship with various components that promote their business, such as customers, people in the community, and related individuals. In addition, corporate image also influences the behavior of stakeholders. Good corporate image has a direct impact on the stakeholders and enhances the trend of attracting qualified staff and profitability [20].

\subsection{Store Image}

From a consumer perspective, buying products may be not only just a demand for such products, but it also is involved with the experience, sense, or other factors [21], including location, type of products, price, promotion, advertising, and shop atmosphere, which all influence the purchasing behavior of consumers. The image of the store can also help consumers distinguish it from other stores [22]. The store image is an ingredient or a combination of tangible and intangible things, such as environment, product placement, impression, sense, design, and atmosphere. Therefore, the businesses should understand and develop their retail stores to most satisfy or attract the consumers. Researchers have given the definition of store image as follows: Store image is a combination of features, such as location, size, and duration of opening hours, the attractiveness of store decoration, employee friendliness, and appreciation of services arising from consumers' perception [23]. It also includes the overviews and stories that cus- 
tomers have in their mind, including their evaluations for selection of stores and brands as well as prior perceptions and experiences about the different features of the stores [24] [25]. It is possible to conclude that store image is an overview of the customers' experiences or perceptions of the store's features, decoration, duration, variety, or other things that affect the choice of the services.

A good store image can help retailers to have an appropriate marketing position and competitive advantage and to differentiate themselves from other retailers. More importantly, the image attached to the consumer's mind is one of the key marketing assets for the success of retail stores and contributes to the loyalty of their stores as well [25]. Store image is therefore part of the corporate image.

\section{Research Methodology}

Primary data were obtained from ten convenience stores (samples) and from observing the characteristics of each retail store in terms of their external environment and internal atmosphere, products, and service employees.

Qualitative data analysis was conducted for symbolic image and functional image.

Quantitative data analysis was conducted by scoring each area (on a scale of one to ten) and using descriptive statistics, K-mean division, and exploratory factor analysis.

Hence this particular research is preminary study based with small samples (of 10 convenience stores from different areas in Bangkok) have been conducted where their results and extra information from the fact observing process (of the different dimentions) are utilized. Ultimately, the satisfaction assessment will be done based on the opinion of the 3 observers (customers) followed by the mean finding process.

\section{Results}

\subsection{Observation}

According to the ten observation retail stores, the characteristics of each retail store are as follows:

1) They are open 24 hours (temporal support).

2) Their cleanliness is shown in Table 2.

From Table 2, the convenience stores design their identities of hygiene and cleanliness as well as focus on fault recovery management, such as dirty floor with garbage. Six stores manage their cleanliness efficiently.

3) Their atmosphere is shown in Table 3.

From Table 3, the convenience stores design their identities of store layout, allocation of spaces, and merchandising and display. For example, the layout of their stores is designed as grid by placing the products in a long line with a corridor for customers who can walk and shop their desired products at a glance. In addition, some stores use the lighting to enhance their service identity (24-hour service), including the music and advertising to stimulate the enjoyment. Six 
Table 2. Store Management in term of cleanliness.

\begin{tabular}{|c|c|c|}
\hline Characteristic & & Description \\
\hline \multirow[t]{10}{*}{ Cleanliness } & Store 1 & Floor is stained and dirty. Equipment for warming food is stained. \\
\hline & Store 2 & The Floor is stained with black spots at some points. \\
\hline & Store 3 & Outside and inside areas are clean. \\
\hline & Store 4 & Outside and inside areas are clean. \\
\hline & Store 5 & $\begin{array}{l}\text { The Inside area is stained by products spilled on the floor (with fast } \\
\text { cleaning). }\end{array}$ \\
\hline & Store 6 & $\begin{array}{l}\text { Inside area is stained and dirty (no staff to clean and left for long) with } \\
\text { trash overflowing }\end{array}$ \\
\hline & Store 7 & $\begin{array}{l}\text { Inside area is stained by spilled products (with fast cleaning and slip- } \\
\text { pery floor warning). }\end{array}$ \\
\hline & Store 8 & Outside and inside areas are clean with no stain or dirt. \\
\hline & Store 9 & $\begin{array}{l}\text { Inside area is stained by spilled products with rubbish on the floor } \\
\text { (with fast cleaning). }\end{array}$ \\
\hline & Store 10 & Inside area is dirty and stained by spilled products (with fast cleaning). \\
\hline
\end{tabular}

Table 3. Store Management in term of atmosphere.

\begin{tabular}{|c|c|c|}
\hline Characteristic & & Description \\
\hline \multirow[t]{10}{*}{ Atmosphere } & Store 1 & Store is small and old with narrow corridor. Inside light is bright. \\
\hline & Store 2 & Store is large with wide service area and corridor. \\
\hline & Store 3 & Store is bright and new with music and brand advertising. \\
\hline & Store 4 & Store is bright and new with music and brand advertising. \\
\hline & Store 5 & $\begin{array}{l}\text { Store is bright and new with narrow service area and corridor. It is } \\
\text { quite cramped. }\end{array}$ \\
\hline & Store 6 & Store is bright and new. Employees loudly shout and play all the time. \\
\hline & Store 7 & $\begin{array}{l}\text { Store is bright and new with wide service area and corridor. It is quite } \\
\text { cramped. }\end{array}$ \\
\hline & Store 8 & $\begin{array}{l}\text { Store is bright and new with wide service area and corridor, music, and } \\
\text { brand advertising, including many payment points. }\end{array}$ \\
\hline & Store 9 & $\begin{array}{l}\text { Store is bright and new with wide service area and corridor, music, and } \\
\text { advertising. }\end{array}$ \\
\hline & Store 10 & $\begin{array}{l}\text { Store is bright with narrow service area and corridor. When arranging } \\
\text { the products, the corridor is obstructed. }\end{array}$ \\
\hline
\end{tabular}

stores manage their atmosphere efficiently.

4) Their product is shown in Table 4.

From Table 4, the convenience stores design their identity of product variety to meet the needs of their customers and the number of their products increases based on spatial location. Therefore, the product identities of the convenience stores consist of core identity, i.e. product variety, and additional identity, i.e. products are offered based on spatial location; for example, stationery products are offered near a school, cosmetics and ordinary drugs are offered near a hos- 
pital, laundry service is offered in or near a condo, and offerings for monks are offered near a temple. The management of products as an identity of the convenience store business in terms of spatial support is shown in Figure 3.

5) Their shelves are shown in Table 5.

From Table 5, the convenience stores design their identity of product placement on the shelves based on the physical characteristics of products; for example, beverage products, are placed near the storage room where the products can be filled from the back of the refrigerator. In addition, the placement of products on each level of the shelves is based on the adjacent department way; for example, ready-to-eat products are placed close to the drinks. Moreover, some products are placed at the point of purchase areas to increase the chances of impulse purchasing. Three stores manage their products on the shelves efficiently.

6) Their employee are shown in Table 6.

Table 4. Store Management in term of products.

\begin{tabular}{|c|c|c|}
\hline Characteristic & & Description \\
\hline \multirow[t]{10}{*}{ Products } & Store 1 & $\begin{array}{l}\text { There are many types of products and snacks. } \\
\text { Location: Community (front of a village) }\end{array}$ \\
\hline & Store 2 & $\begin{array}{l}\text { There are many types of products that are different from those of other stores, such } \\
\text { as neck pillow and blindfold. } \\
\text { Location: In a gas station }\end{array}$ \\
\hline & Store 3 & $\begin{array}{l}\text { There are many types of products with several redemption promotions. } \\
\text { Location: Community (fresh market) }\end{array}$ \\
\hline & Store 4 & $\begin{array}{l}\text { There are many types of products that are different from those of other branches, } \\
\text { such as fresh vegetable and fruits and freshly cooked foods (porridge, lava eggs, and } \\
\text { egg pans), including laundry service. } \\
\text { Location: Community (under a condo building) }\end{array}$ \\
\hline & Store 5 & $\begin{array}{l}\text { There are many types of products, especially ready-to-eat products (need to be } \\
\text { warmed by microwave oven), everyday small appliances, and cosmetics. } \\
\text { Location: In a hospital }\end{array}$ \\
\hline & Store 6 & $\begin{array}{l}\text { There are many types of products. } \\
\text { Location: Community and industrial factory }\end{array}$ \\
\hline & Store 7 & $\begin{array}{l}\text { There are many types of products that are different from those of other branches, } \\
\text { such as offerings for monks. } \\
\text { Location: Near a temple }\end{array}$ \\
\hline & Store 8 & $\begin{array}{l}\text { There are many types of products, including freshly cooked foods and breads. } \\
\text { Location: Silom (Soi Convent) }\end{array}$ \\
\hline & Store 9 & $\begin{array}{l}\text { There are many types of products, especially cosmetics and ordinary drugs. } \\
\text { Location: Salaya (near a hospital) }\end{array}$ \\
\hline & Store 10 & $\begin{array}{l}\text { There are many types of products, especially stationery. } \\
\text { Location: Thammasat University (Tha Prachan) }\end{array}$ \\
\hline
\end{tabular}

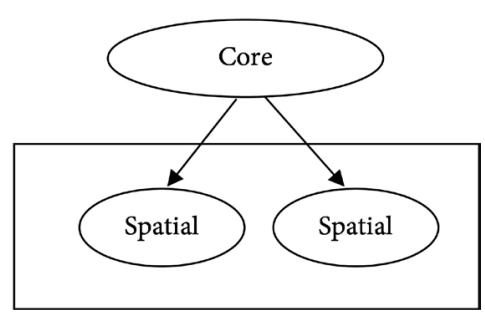

Figure 3. Product identity of convenience stores. 
Table 5. Store Management in term of shelves.

\begin{tabular}{ccl}
\hline Characteristic & \multicolumn{1}{c}{ Description } \\
\hline Shelves & Store 1 & Product types and zones are clearly classified. Shelves are not full. \\
Store 2 & $\begin{array}{l}\text { Product types and zones are clearly classified. Shelves are full and in order } \\
\text { (brands are alternately placed). }\end{array}$ \\
Store 3 & $\begin{array}{l}\text { Product types and zones are clearly classified. Shelves are full and in order } \\
\text { (but products near their expiry dates are placed on the back). }\end{array}$ \\
Store 4 & $\begin{array}{l}\text { Product types and zones are clearly classified. Many points on the shelves } \\
\text { are empty. }\end{array}$ \\
Store 5 & $\begin{array}{l}\text { Product types and zones are clearly classified. Many points on the shelves } \\
\text { are empty. }\end{array}$ \\
Store 6 & $\begin{array}{l}\text { Product types and zones are clearly classified. Many points on the shelves } \\
\text { are empty. Products are randomly and alternately placed (shampoos are } \\
\text { placed with shower creams). Many products are placed on the payment } \\
\text { counter. }\end{array}$ \\
Store 10 & $\begin{array}{l}\text { Product types and zones are clearly classified. Many points on the shelves } \\
\text { Promotion products are placed at a special area (redemption products). } \\
\text { are empty. Products are randomly placed. Many products are placed on the } \\
\text { payment counter. }\end{array}$ \\
Store 8 & $\begin{array}{l}\text { Product types and zones are clearly classified. Shelves are full and in order. } \\
\text { Promotion products are placed at a special area (redemption products). } \\
\text { Product types and zones are clearly classified. Shelves are full and in order. } \\
\text { Promotion products are placed at a special area (redemption products). }\end{array}$ \\
& &
\end{tabular}

Table 6. Store Management in term of employees.

\begin{tabular}{|c|c|c|}
\hline Characteristic & & Description \\
\hline \multirow[t]{10}{*}{ Shelves } & Store 1 & Small number ( 2 employees) who talk to each other all the time. \\
\hline & Store 2 & $\begin{array}{l}\text { Appropriate number ( } 4 \text { employees) who provide quick services and } \\
\text { suggest other products. }\end{array}$ \\
\hline & Store 3 & $\begin{array}{l}\text { Large number ( } 5 \text { employees) who provide quick services, suggest other } \\
\text { products, arrange the product frequently, and remember and greet their } \\
\text { customers. }\end{array}$ \\
\hline & Store 4 & $\begin{array}{l}\text { Appropriate number ( } 3 \text { - } 4 \text { employees) who provide quick services, } \\
\text { suggest other products, and remember and greet their customers. }\end{array}$ \\
\hline & Store 5 & Large number (5 employees) who provide quick services. \\
\hline & Store 6 & $\begin{array}{l}\text { Appropriate number ( } 4 \text { employees) who talk to each other, give customers } \\
\text { a long wait, serve impatiently, and eat behind payment counter. }\end{array}$ \\
\hline & Store 7 & Large number (6 employees) who provide quick and polite services. \\
\hline & Store 8 & Large number (6 employees) who provide quick and polite services. \\
\hline & Store 9 & $\begin{array}{l}\text { Large number ( } 4 \text { - } 5 \text { employees) who provide quick and polite services and } \\
\text { suggest other products, promotions, and discounts. }\end{array}$ \\
\hline & Store 10 & $\begin{array}{l}\text { Large number ( } 4-5 \text { employees) who provide quick and polite services and } \\
\text { suggest other products, promotions, and discounts. }\end{array}$ \\
\hline
\end{tabular}


From Table 6, the convenience stores design their identity of employees based on employee management, training, and customer services, such as food warming for customers. In addition, they reinforce customers to increase the opportunity to sell products with their words as a stimulus, such as persuading to buy more product, suggesting promotion or redemption products, or providing quick services. Eight stores manage their employees efficiently.

7) General customers of these stores may be those who live or work close to the store locations or who pass the stores.

\subsection{Data Analysis}

The results of the data analysis from the scores of seven observations in all stores grouped by K-Means (two groups) are shown in Figure 4.

Figure 4(a) and Figure 4(b) shows the scores of each group of stores classified by K-Means. The first group consists of 8 stores and the second group consists of 2 stores. The meaning in each item is as follows:

- Convenience: service duration and location.

- Cleanliness: clean areas, shelves, and equipment for services.

- Atmosphere: store layout, shelf area and atmosphere creation with light, colors and music.

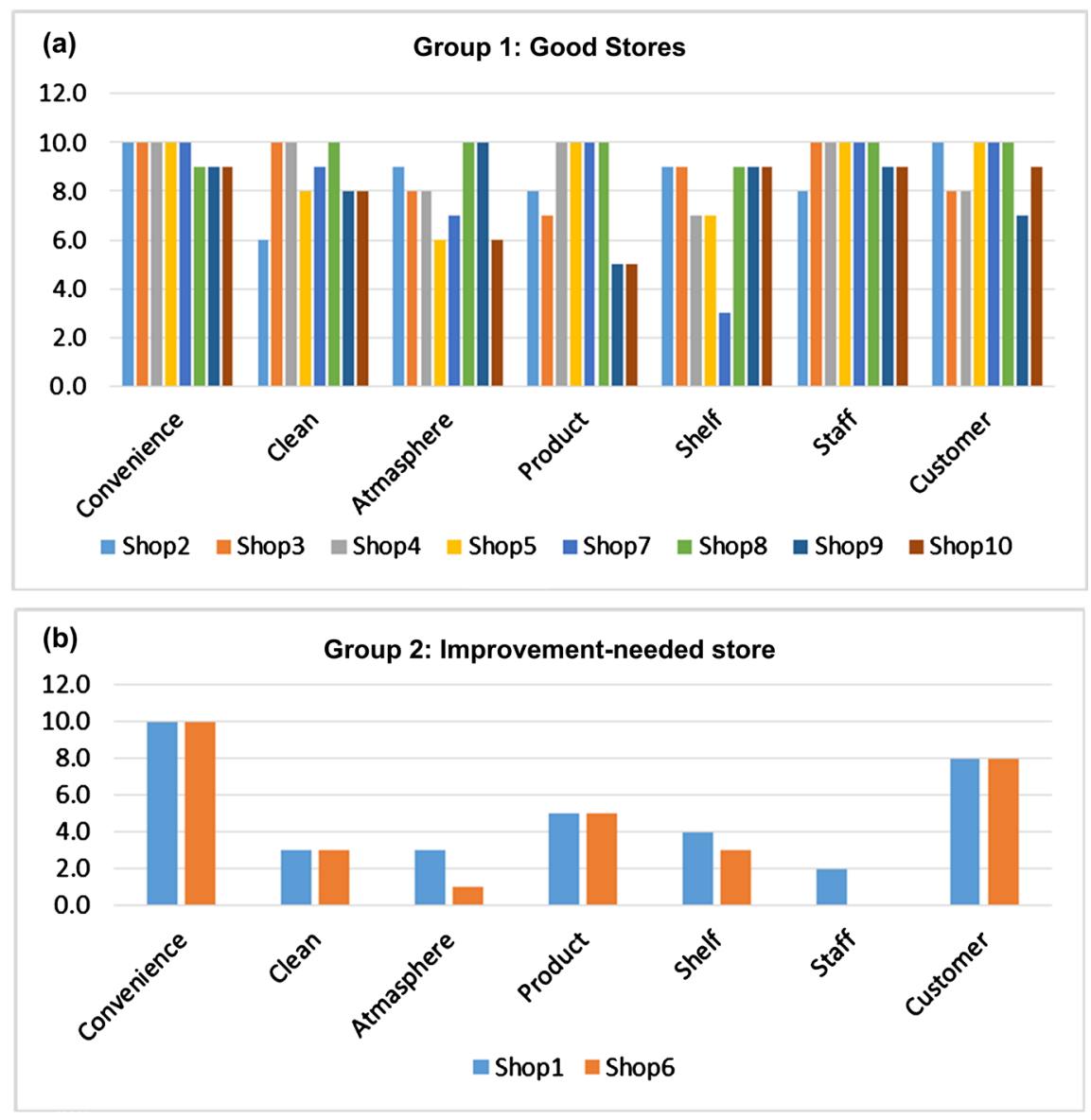

Figure 4. Groups of stores with good and bad images. 
- Product: products.

- Shelf: product placement of the shelves (orderliness) and classification of products.

- Staff: employee who provide services and sell products in the stores.

- Customer: satisfaction of customers who come to the stores to buy products or services.

According to the scoring based on consumer observations seven images of the stores were clearly divided, i.e. eight stores had a good image as a whole and two stores had a bad image as a whole. It may be concluded that 20 percent of the convenience stores have poor image management at the downstream in terms of cleanliness, atmosphere, and employees. Customers can experience directly and it eventually becomes customer satisfaction in the end.

\subsection{Factor Analysis}

The results of the data analysis based on the factor analysis are shown in Table 7.

According to the factor analysis, the variables were divided into two factors: first factor includes Shelf, Atmosphere, Staff, Cleanliness, and Convenience with a weight of $0.888,0.877,0.781,0.761$, and 0.722 , respectively, and second factor includes Product and Customer with a weight of 0.951 and 0.775 , respectively. The first factor was named Storefront Management and the second factor was named Product and Customer Management as shown in Figure 5.

\section{Discussion and Conclusion}

According to the results of this study, it can be summarized that the components and characteristics of the retail stores in terms of convenience (service duration and location), environment (cleanliness, product shelf layout and placement, and atmosphere), product (variety and promotion), and quality services all have a direct impact on corporate image, both positively and negatively, in the customer's perception. Therefore, the store employees who work and contact with their customers directly should be aware of their duties and appropriate store

Table 7. Factor analysis of seven variables.

\begin{tabular}{ccc}
\hline & \multicolumn{2}{c}{ Rotated Component Matrix ${ }^{\mathrm{a}}$} \\
\hline & 1 & Component \\
\hline Shelf & 0.888 & 2 \\
Atmosphere & 0.877 & -0.062 \\
Staff & 0.781 & 0.317 \\
Cleanliness & 0.761 & 0.565 \\
Convenience & -0.722 & 0.515 \\
Product & 0.151 & 0.392 \\
Customer & -0.01 & 0.951 \\
& & 0.775 \\
\hline
\end{tabular}




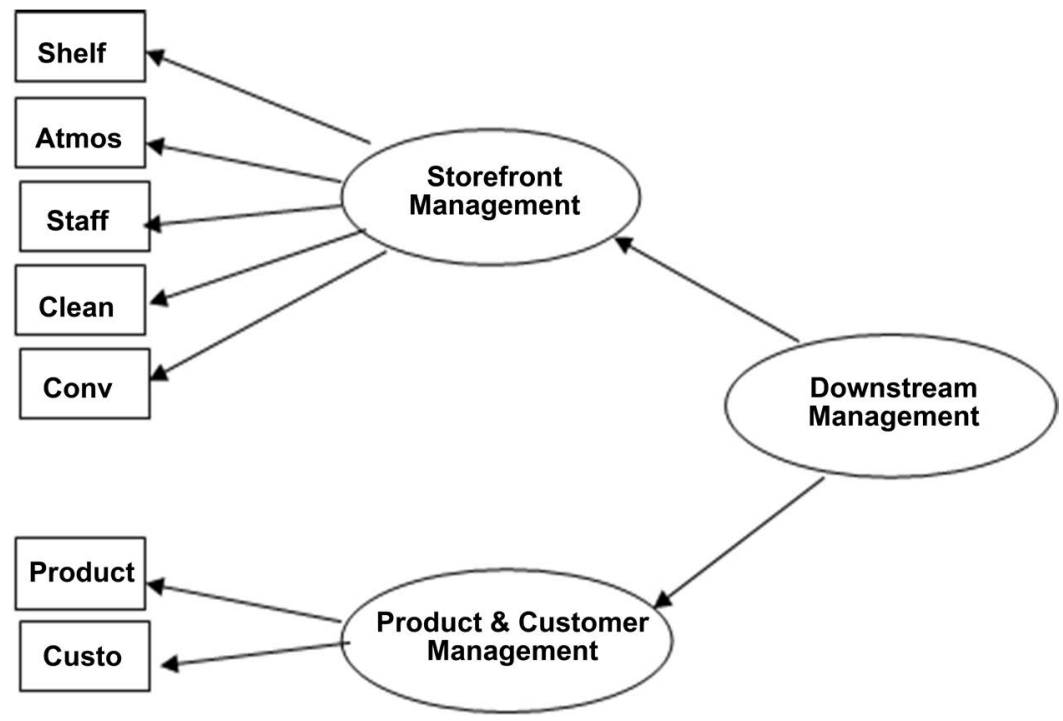

Figure 5. Metric model in the factor analysis of convenience store management at downstream.

management so that good and quality products and services are given to customers to obtain their expected experience and impression. According to Philip T. Kotler and Kevin Lane Keller in their book, Marketing Management $\left(14^{\text {th }}\right.$ Edition), there are two factors that affect the quality and impression of the services: expected services and perceived services. Thus, if the organizations want to build customer loyalty continuously, they must offer quality services to their customers continuously as well as offer better services than the expectations of consumers because it can eventually lead to customer satisfaction and impression [26]. As mentioned by researchers, such as Almendros, Crespo \& Garcia, and Del Barrio, a good presentation of products and services or a good customer service can create a good image and is a very effective practice when compared with the media campaigns presented by the company [27]. Therefore, the corporate image management of the convenience stores at the downstream is important for the satisfaction of customers who finally think of, visit and shop at the stores frequently becoming the loyalty in the end [28] [29].

\section{Future Research}

Based on the results of this pilot study regarding corporate image communication through the store management process and the product and customer management process operated by store employees, the future research should investigate the employee management factors in various aspects, such as store management, customer management, product management, and fault recovery management, which will affect the ability of the store management to create customer perception of corporate image.

\section{Conflicts of Interest}

The authors declare no conflicts of interest regarding the publication of this pa- 
per.

\section{References}

[1] VanderWagen, L. (2005) Building Quality Service with Competency Based Human Resource Management. Jaico Publ., Mumbai.

[2] Grönroos, C. (2005) Service Management and Marketing. Wiley, Chichester.

[3] Sina, A. and Kim, H. (2018) Enhancing Consumer Satisfaction and Retail Patronage through Brand Experience, Cognitive Pleasure, and Shopping Enjoyment: A Comparison between Lifestyle and Product-Centric Displays. Global Fashion Management Conference, 1489-1490. https://doi.org/10.15444/GMC2018.12.07.03

[4] MacInnis, D. and Price, L. (1987) The Role of Imagery in Information Processing: Review and Extensions. Journal of Consumer Research, 13, 473-491. https://doi.org/10.1086/209082

[5] Thang, D. and Tan, B. (2003) Linking Consumer Perception to Preference of Retail Stores: An Empirical Assessment of the Multi-Attributes of Store Image. Journal of Retailing and Consumer Services, 10, 193-200.

https://doi.org/10.1016/S0969-6989(02)00006-1

[6] Hosseini, Z., Jayashree, S. and Malarvizhi, C. (2014) Store Image and Its Effect on Customer Perception of Retail Stores. Asian Social Science, 10. https://doi.org/10.5539/ass.v10n21p223

[7] Hilman, H. and Hanaysha, J. (2015) The Impact of Country of Origin on Relationship Quality: Empirical Evidence from Automotive Industry. Mediterranean Journal of Social Sciences, 6, 165-174. https://doi.org/10.5901/mjss.2015.v6n2p165

[8] Putra, R., Hartoyo, H. and Simanjuntak, M. (2017) The Impact of Product Quality, Service Quality, and Customer Loyalty Program Perception on Retail Customer Attitude. Independent Journal of Management \& Production, 8, 1116-1129. https://doi.org/10.14807/ijmp.v8i3.632

[9] Waller, M. and Ahire, S. (1996) Management Perception of the Link between Product Quality and Customers' View of Product Quality. International Journal of Operations \& Production Management, 16, 23-33. https://doi.org/10.1108/01443579610125561

[10] Rachman, A. (2018) The Effect of Product Quality, Service Quality, Customer Value on Customer Satisfaction and Word of Mouth. Journal of Research in Management, 1, 78-95. https://doi.org/10.32424/jorim.v1i3.36

[11] Wu, C., Liao, S., Chen, Y. and Hsu, W. (2011) Service Quality, Brand Image and Price Fairness Impact on the Customer Satisfaction and Loyalty. 2011 IEEE International Conference on Industrial Engineering and Engineering Management, Changchun, 3-5 September 2011, 1160-1164. https://doi.org/10.1109/IEEM.2011.6118097

[12] Porter, S. and Claycomb, C. (1997) The Influence of Brand Recognition on Retail Store Image. Journal of Product \& Brand Management, 6, 373-387. https://doi.org/10.1108/10610429710190414

[13] Bloemer, J., de Ruyter, K. and Peeters, P. (1998) Investigating Drivers of Bank Loyalty: The Complex Relationship between Image, Service Quality and Satisfaction. International Journal of Bank Marketing, 16, 276-286. https://doi.org/10.1108/02652329810245984

[14] Da Silva, R. and Syed Alwi, S. (2007) Online Corporate Brand Image, Satisfaction and Loyalty. Journal of Brand Management, 16, 119-144. 
https://doi.org/10.1057/palgrave.bm.2550137

[15] Lai, F., Griffin, M. and Babin, B. (2009) How Quality, Value, Image, and Satisfaction Create Loyalty at a Chinese Telecom. Journal of Business Research, 62, 980-986. https://doi.org/10.1016/j.jbusres.2008.10.015

[16] Zeithaml, V. (1988) Consumer Perceptions of Price, Quality, and Value: A MeansEnd Model and Synthesis of Evidence. Journal of Marketing, 52, 2-22. https://doi.org/10.1177/002224298805200302

[17] Parasuraman, A., Zeithaml, V. and Berry, L. (1985) A Conceptual Model of Service Quality and Its Implications for Future Research. Journal of Marketing, 49, 41-50. https://doi.org/10.1177/002224298504900403

[18] Hart, A. and Rosenberger, P. (2004) The Effect of Corporate Image in the Formation of Customer Loyalty: An Australian Replication. Australasian Marketing Journal, 12, 88-96. https://doi.org/10.1016/S1441-3582(04)70109-3

[19] Adeniji, A., Osibanjo, A., Abiodun, J. and Oni-Ojo, E. (2015) Corporate Image: A Strategy for Enhancing Customer Loyalty and Profitability. Journal of South African Business Research, 2015, Article ID: 259483. https://doi.org/10.5171/2015.259483

[20] Roberts, P. and Dowling, G. (2002) Corporate Reputation and Sustained Superior Financial Performance. Strategic Management Journal, 23, 1077-1093. https://doi.org/10.1002/smj.274

[21] Jinfeng, W. and Zhilong, T. (2009) The Impact of Selected Store Image Dimensions on Retailer Equity: Evidence from 10 Chinese Hypermarkets. Journal of Retailing and Consumer Services, 16, 486-494.

https://doi.org/10.1016/j.jretconser.2009.08.002

[22] Martineau, P. (1958) The Personality of the Retail Store. Harvard Business Review, 36, 47-55.

[23] Kasulis, J. and Lusch, R. (1981) Validating the Retail Store Image Concept. Journal of the Academy of Marketing Science, 9, 419-435. https://doi.org/10.1007/BF02729882

[24] North, E., De Vos, R. and Kotzé, T. (2010) The Importance of Apparel Product Attributes for Female Buyers. Journal of Family Ecology and Consumer Sciences, 31, 41-51. https://doi.org/10.4314/jfecs.v31i1.52834

[25] Chang, E. and Luan, B. (2010) Chinese Consumers' Perception of Hypermarket Store Image. Asia Pacific Journal of Marketing and Logistics, 22, 512-527. https://doi.org/10.1108/13555851011090538

[26] Pershing, D. (1993) Satisfaction. Bantam Books, New York.

[27] Crespo-Almendros, E. and Del Barrio-García, S. (2014) Do Online Discounts and Free Gifts Damage Brand Image of Service? The Moderating Role of Promotion-Proneness. Service Business, 10, 31-58. https://doi.org/10.1007/s11628-014-0255-9

[28] Arnold, S., Oum, T. and Tigert, D. (1983) Determinant Attributes in Retail Patronage: Seasonal, Temporal, Regional, and International Comparisons. Journal of Marketing Research, 20, 149-157. https://doi.org/10.1177/002224378302000205

[29] Sirgy, M. and Coskun Samli, A. (1985) A Path Analytic Model of Store Loyalty Involving Self-Concept, Store Image, Geographic Loyalty, and Socioeconomic Status. Journal of the Academy of Marketing Science, 13, 265-291. https://doi.org/10.1007/BF02729950 